\title{
Nickel (II)-induced apoptosis and G2/M enrichment
}

\author{
Sang-Han Lee, ${ }^{1,3}$ Do-Kwon Kim, ${ }^{1}$ \\ Young-Rok Seo, ${ }^{2}$ Kee-Min Woo, ${ }^{1}$ \\ Chang-Se Kim ${ }^{1}$ and Man-Hee Cho ${ }^{1}$ \\ 1 Department of Biochemistry, College of Medicine, \\ Soonchunhyang University, Cheon-An 330-090, Korea \\ 2 Toxicology Laboratory, Doping Control Center, KIST, Seoul 136-650, \\ Korea \\ 3 Corresponding author
}

Accepted 3 August 1998

Abbreviations: PBS, phosphate-buffered saline; SDS, sodium dodecyl sulfate; $\mathrm{CHO}$, Chinese hamster ovary

\begin{abstract}
Treatment with certain DNA-damaging agents induce a complex cellular response comprising pertubation of cell cycle progression and/or apoptosis on proliferating mammalian cells. Our studies were focused on the cellular effects of nickel (II) acetate, DNAdamaging agent, on Chinese hamster ovary (CHO) cells. Fragmented DNAs were examined by agarose gel electrophoresis and cell cycle was determined by DNA flow cytometry using propidium iodide fluorescence. Apparent DNA laddering was observed in cells treated with $240 \mu \mathrm{M}$ nickel (II) and increased with a concentration-dependent manner. Treatment of nickel (II) acetate resulted in apoptosis which was accompanied by $G_{2} / M$ cell accumulation. Proportion of $\mathrm{CHO}$ cells in $\mathrm{G}_{2} / \mathrm{M}$ phase was also significantly increased in cells exposed to at least $480 \mu \mathrm{M}$ nickel (II) from $57.7 \%$ of cells in the $\mathrm{G}_{0} / \mathrm{G}_{1}$ phase, $34.7 \%$ in the $S$ phase, and $7.6 \%$ in the $\mathrm{G}_{2} / \mathrm{M}$ phase for $0 \mu \mathrm{M}$ nickel (II), to $58.6 \%, 14.5 \%$, and $26.9 \%$ for $640 \mu \mathrm{M}$ nickel (II). These findings suggest that nickel (II) can modulate cellular response through some common effectors involving in both apoptotic and cell cycle regulatory pathways.
\end{abstract}

Keywords: DNA damage, apoptosis, cell cycle, flow cytometry, Sub-G1, DNA ladder

\section{Introduction}

The critical balance between cell proliferation and death is imperative for the survival of multicellular organisms.
Apoptosis, or programmed cell death, is an active, genetically controlled process which allows an organism to eliminate unwanted cells through a safe, orderly process (Wyllie, 1980). Apoptosis is characterized morphologically by cell shrinkage, apoptotic body formation, chromatin condensation and fragmentation, and biochemically by cleavage of DNA into oligonucleosomal DNA fragments. The latter process results in DNA ladders on agarose gel electrophoresis (Walker et al., 1995).

In many cultured cell lines, apoptosis can be readily triggered by DNA-damaging agents (Allday et al., 1995), $\gamma$-irradiation (Sellins and Cohen, 1991), activation of Fas/ Apo1 receptor (Watanabe-Fukanaga et al., 1992), or some anticancer agents (Lowe et al., 1993). Activation of the cell death pathway is a safeguard to remove unrepairably damaged cells. Cells also can be restricted to a particular phase of cell cycle for the entry into apoptosis, although this cell cycle dependence does not appear to be a general process. Damaged cells stop DNA replication at $G_{1}$ (Dulic et al., 1994) or $G_{2}$ phase (O'Connor et al., 1993). The arrest at the $G_{1}$ and $G_{2}$ checkpoints indicates the necessity of the cells to gain time to repair the damaged DNA before the next round of cell cycle. It seems that cell proliferation and apoptosis are intrinsically linked, if not in all situations, at least in many. Recent studies have suggested an intricate relationship between apoptosis and cell cycle (King and Cidlowski, 1995). However, it is yet unclear whether cell cycle arrest is a prerequisite for the activation of the apoptotic process.

In an effort to find the link between cell proliferation and cell death, we first examined the induction of apoptosis and the cell cycle distribution in Chinese hamster ovary $(\mathrm{CHO})$ cells treated with different quantities of nickel (II) acetate which induces genotoxic effects such as DNA-protein crosslinking, DNA strand breaks, sister chromatid exchange, and oxidative DNA base damage (Kasprzak, 1995).

\section{Materials and Methods}

\section{Cell culture and treatment}

Chinese hamster ovary cell variant, $\mathrm{CHO}-\mathrm{K} 1-\mathrm{BH} 4$, grew in a monolayer culture in Ham's F-12 medium (Biofluids, Inc., Rockville, MD) supplemented with $5 \%$ fetal bovine serum, $1 \mathrm{mM}$ glutamine, 100 unit of penicillin/ml, and $100 \mu \mathrm{g}$ of streptomycin $/ \mathrm{ml}$. Cultures were maintained at $37^{\circ} \mathrm{C}$ in a humidified air containing $5 \% \mathrm{CO}_{2}$. To eliminate the possible interfering factor such as confluencyinduced apoptosis (Brezden and Rauth et al., 1996), the cells were differently seeded in $10-\mathrm{cm}$ diameter culture 
plates, $5 \times 10^{5}$ or $1 \times 10^{6}$ cells/plate, $24 \mathrm{~h}$ prior to the addition of nickel (II) acetate (Sigma, St. Louis, MO), freshly dissolved in the above medium. Plates seeded with $5 \times 10^{5}$ cells were used for treatments with 0,40 , 80 , and $160 \mu \mathrm{M}$ nickel (II) and plates seeded with $1 \times$ $10^{6}$ cells were used for treatments with $240,360,480$, and $640 \mu \mathrm{M}$ nickel (II). The cells were incubated with nickel (II) acetate for 24,48 , and $72 \mathrm{~h}$. They were then harvested with $2 \mathrm{ml}$ trypsin $(0.25 \% \mathrm{w} / \mathrm{v}$, without calcium and magnesium, Biofluids, Inc.) for DNA flow cytometry and DNA fragmentation assay.

\section{Laser Scanning Microscopy}

Cells were grown on coverslips for 3 days, and treated with $240 \mu \mathrm{M}$ nickel (II) acetate for 3 days. The media were removed, and then the cells were stained by direct applying with acridine orange (Sigma, St. Louis, MO; 40 $\mu \mathrm{g} / \mathrm{ml}$ in PBS) and ethidium bromide (Sigma; $20 \mu \mathrm{g} / \mathrm{ml}$ in PBS). Following washing once with PBS with special care to avoid the excessive cell loss, the coverslip was mounted on a slide and then observed with a LSM 410 laser scanning microscope (Carl Zeiss, Jena, Germany).

\section{Analysis of DNA ladder for apoptosis}

The analysis for DNA fragmentation was carried out by the method described by Gong et al. (1993). The floating and attached cells from each plate were pooled by centrifugation and fixed in $70 \%$ ethanol at $-20^{\circ} \mathrm{C}$ for 72 $\mathrm{h}$. The cells were then centrifuged at $800 \mathrm{~g}$ for $5 \mathrm{~min}$ and the cell pellets $\left(1-2 \times 10^{6}\right)$ were resuspended in $40 \mu \mathrm{l}$ of phosphate-citrate (PC) buffer, consisting of 192 parts of $0.2 \mathrm{M} \mathrm{Na}_{2} \mathrm{HPO}_{4}$ and 8 parts of $0.1 \mathrm{M}$ citric acid $(\mathrm{pH} 7.8)$ for at least $30 \mathrm{~min}$. After centrifugation at $1000 \mathrm{~g}$ for 5 min, cell pellets were used in cell cycle analysis and the supernatant was transferred to new tube and concentrated by vacuum in Speed Vac concentrator for $20 \mathrm{~min}$. A $5 \mu \mathrm{l}$ of a solution of DNase-free RNase (Sigma; $0.4 \mathrm{mg} / \mathrm{ml}$ ) was then added. After $1 \mathrm{~h}$ incubation at $37^{\circ} \mathrm{C}, 5 \mu \mathrm{l}$ of a solution of proteinase $\mathrm{K}$ (Sigma; $0.4 \mathrm{mg} / \mathrm{ml}$ ) was added and extract was incubated for an additional $1 \mathrm{~h}$ at $37^{\circ} \mathrm{C}$. After the incubation, $12 \mu$ l of loading buffer $(0.25 \%$ bromphenol blue, $0.25 \%$ xylene cyanol, $30 \%$ glycerol) was added and the entire content of the tube was transferred to the gel. The DNA ladder was resolved in a $1.8 \%$ agarose gel and visualized by ethidium bromide $(0.5 \mu \mathrm{g} / \mathrm{ml})$ staining.

\section{Flow cytometry}

Cell pellets removed from the PC buffer described above were resuspended in $200 \mu \mathrm{l}$ of Hanks' buffered salt solution (HBSS) and counted with a hemocytometer. The cells (approximately $1 \times 10^{6}$ cells $/ \mathrm{ml}$ ) were then incubated with DNase-free RNase $(0.1 \mathrm{mg} / \mathrm{ml}$, Sigma) and propidium iodide ( $50 \mu \mathrm{g} / \mathrm{ml}$, Sigma) at $4^{\circ} \mathrm{C}$ for at least $1 \mathrm{~h}$ prior to flow cytometric analysis. The propidium iodide-stained cells were assayed at $488 \mathrm{~nm}$ on an EPICS Profile flow cytometer (Coulter, Hialeah, FL) equipped with an air-cooled $20 \mathrm{~mW}$ argon laser. A minimum of 10,000 cells were collected in each run. The cells were selected by pulse-height (doublet elimination) analysis and only the integrated signals were collected to reject doublets. All histograms were evaluated by Multicycle software (Advanced version, Phoenix Flow Systems, San Diego, CA) (Kallioniemi et al., 1994). The G0/G1 and G2/M peaks were determined using Gaussian curves. Resolution of $\mathrm{G}_{0} / \mathrm{G}_{1}$ peaks was evaluated by coefficient of variation which is calculated by dividing the half-peak width by the mean channel number. The $S$ phase fraction was calculated by the area under the zero order polynomial curve between mean channel number of $G_{0} / G_{1}$ peak and that of G2/M peak.

\section{Statistical analysis}

Statistical evaluation of the data was performed either by analysis of variance (ANOVA) or by Student's $t$-test for paired comparisons. Trends were examined by linear regression statistics using the SAS program. Differences with probability values $\leq 0.05$ were considered to be statistically significant.

\section{Results and Discussion}

\section{CHO cell morphology}

Morphological changes in response to the treatment of $\mathrm{CHO}$ cells with nickel (II) acetate were examined by confocal microscopy after staining with acridine orange. Nuclear fragmentation, indicative of apoptosis, was apparent in $240 \mu \mathrm{M}$ treated adherent cells at day 3 after treatment (Figure 1). Also at this time, $18 \%$ of the adherent cells exhibited pyknotic, fragmented nuclei. Phase-contrast microscopy of $\mathrm{CHO}$ cells treated with 480 $\mu \mathrm{M}$ nickel (II) acetate for $72 \mathrm{~h}$ showed an epithelial celllike morphology of untreated $\mathrm{CHO}$ cells to be elongated and resembled fibroblasts (Figure 2). The elongation developed in the first $24 \mathrm{~h}$ of nickel (II) acetate and persisted throughout the remaining $72 \mathrm{~h}$ of exposure. The change in morphology of $\mathrm{CHO}$ cells has been reported to be associated with increased intracellular cAMP concentrations and activation of CAMP-dependent protein kinase (Costa, 1978).

\section{DNA fragmentation assay}

In initial assays of DNA fragmentation, the untreated control cells and cells treated with $\leq 240 \mu \mathrm{M}$ nickel (II) acetate proliferated rapidly and reached $90-95 \%$ confluency $72 \mathrm{~h}$ after treatment. The doubling time of untreated cells was determined to be $14 \pm 1 \mathrm{~h}$. In contrast, cells treated with $640 \mu \mathrm{M}$ nickel (II) acetate proliferate more slowly, and reached only $\sim 50 \%$ confluency. Fragmented 


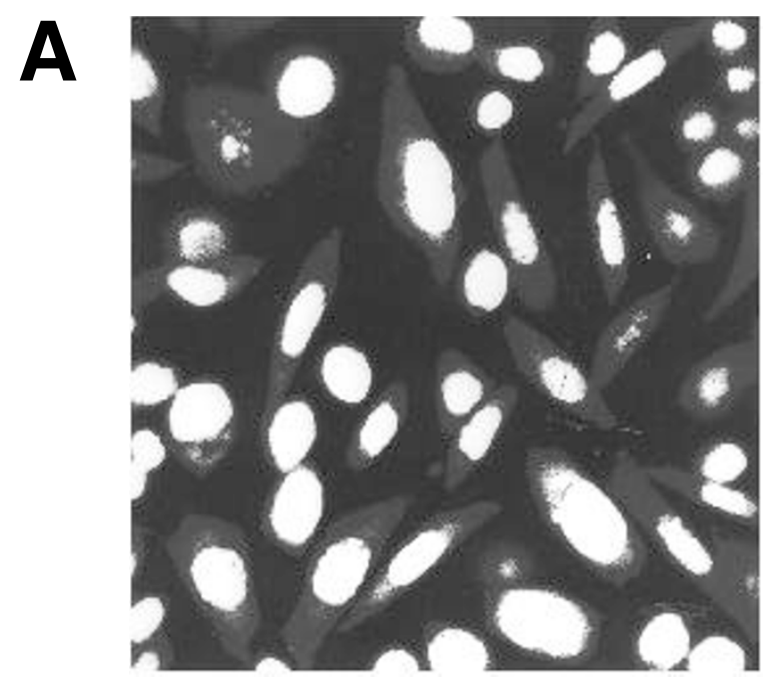

B

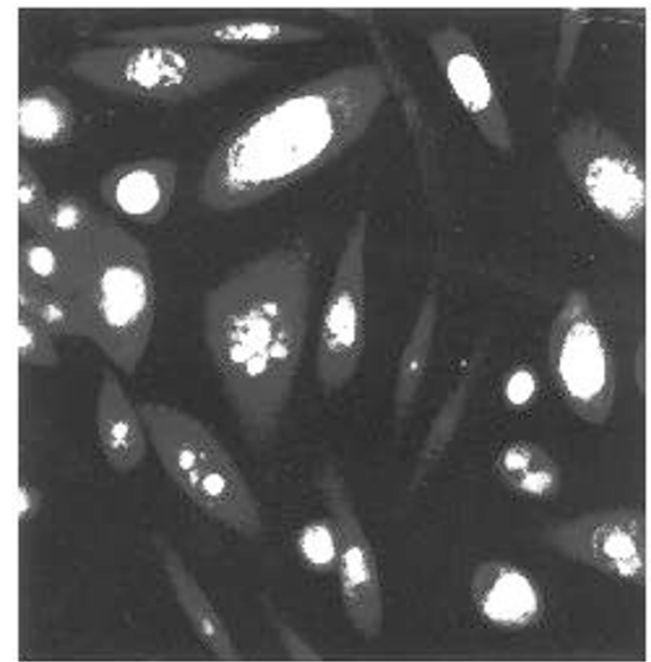

Figure 1. Confocal microscopic finding showing nuclear fragmentation as morphological criteria of apoptosis in nickel (II) acetate-treated $\mathrm{CHO}$ cells. Cells were grown on coverslips and treated with 240 (M nickel (II) acetate for $72 \mathrm{~h}$. Morphology of untreated cells $(A)$ and treated cells $(B)$ was identified by acridine orange/ethidium bromide staining.

DNAs pooled from adherent and floating cells were analyzed by $1.8 \%$ agarose gel electrophoresis (Figure $3 A)$. Internucleosomal DNA fragmentation was faintly detected in cells treated with $160 \mu \mathrm{M}$ nickel (II) acetate, and its intensity increased markedly with the rising concentration of nickel (II) acetate.

Figure 3B shows an agarose gel electrophoresis of fragmented DNAs isolated from pooled nonadherent and adherent cells at various times after nickel (II) treatment. DNA ladder was faintly detected in $48 \mathrm{~h}$ of exposure. But it was clearly evident following $72 \mathrm{~h}$ nickel (II) acetate exposure. As determined in comparison with molecular weight marker DNA, the average size
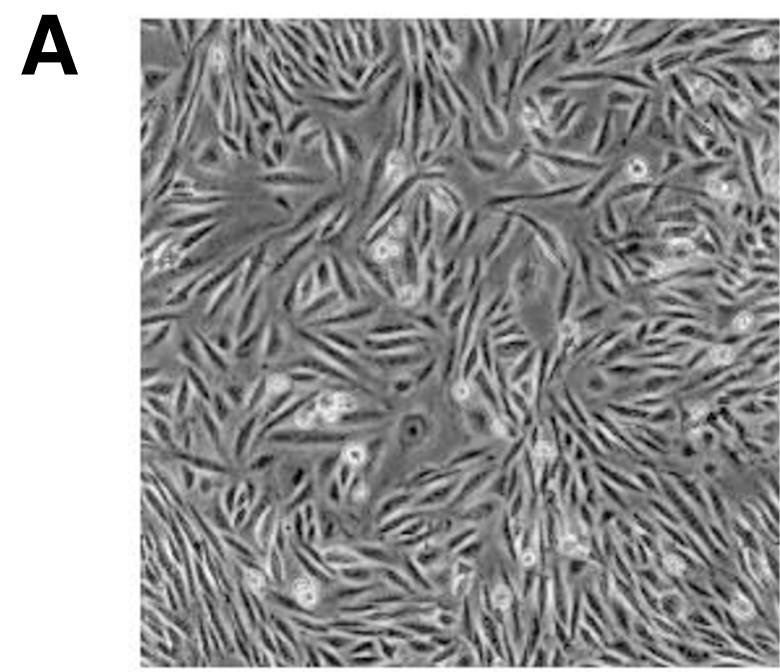

B

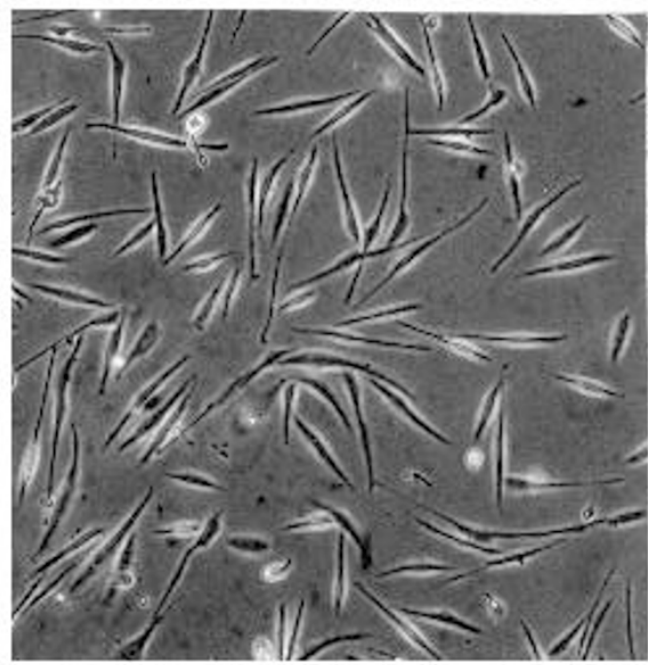

Figure 2. Phase-contrast microscopic finding showing morphological change in nickel (II) acetate-treated CHO cells: (A) untreated, (B) treated with 480 (M nickel (II) acetate for $72 \mathrm{~h}$

difference between the DNA fragments was approximately $180 \mathrm{bp}$ (Orren et al., 1977). This fragmentation pattern is consistent with the molecular weight expected to result from the inter-nucleosomal DNA cleavage associated with apoptotic cell death. Nickel (II)-induced apoptosis has been once reported but the findings are not consistent with our results. Myeloid precursor cell line HL-60, but not murine fibro-blasts L929 nor gingival fibroblasts, showed an indication of apoptosis after exposure to $1 \mathrm{mM}$ nickel (II) (Schedle et al., 1995). These differences probably could be cellspecific and/or associated with nickel (II) concentration.

\section{Cell cycle analysis}

Cell cycle analysis after nickel (II) acetate treatment for $72 \mathrm{~h}$ revealed the percentage of cells in the $S$ phase 
tended to decrease and that in $\mathrm{G}_{2} / \mathrm{M}$ phase tended to increase with the increasing nickel (II) concentration (Figure 4). As revealed by trend analysis, those overall tendencies were significant with $P<0.001$. The decrease in the $S$ phase cell proportion was statistically significant at $\geq 320 \mu \mathrm{M}$ nickel (II), and the increase in the $\mathrm{G}_{2} / \mathrm{M}$ phase cells, indicative of an arrest, was significant in samples treated with $\geq 480 \mu \mathrm{M}$ nickel (II) acetate $(P<0.01)$. The occurrence of a sub- $G_{1}$ peak, typical of apoptosis (Darzynkiewicz et al., 1992), was detected in cells treated with $480 \geq \mu \mathrm{M}$ nickel (II) acetate and its peak increased with the rising nickel (II) concentration. Table 1 shows that untreated $\mathrm{CHO}$ cells for $72 \mathrm{~h}$ displayed a typical distribution of $57.7 \%$ in $G_{0} / G_{1}$ phase, $34.7 \%$ in the $S$ phase, and $7.6 \%$ in $\mathrm{G}_{2} / \mathrm{M}$ phase. But the treatment of cells with 640 (M nickel (II) acetate for $72 \mathrm{~h}$ increased the number of cells in $\mathrm{G}_{2} / \mathrm{M}$ to $26.9 \%$ whereas the number of cells in the S-phase decreased $14.5 \%$. Cell cycle distributions in 24 and $48 \mathrm{~h}$ were also examined

A

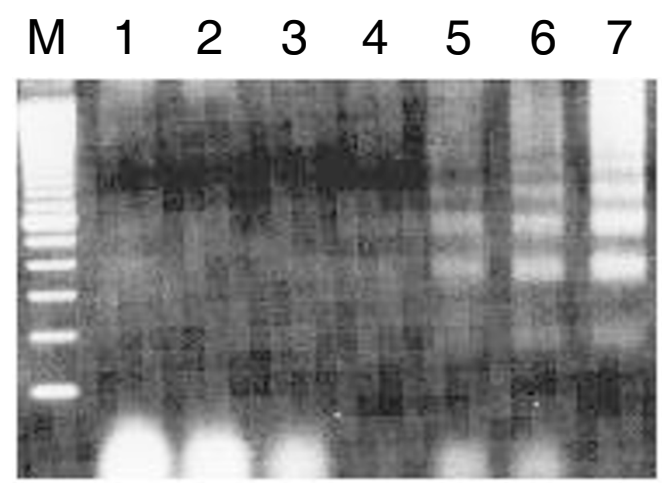

B
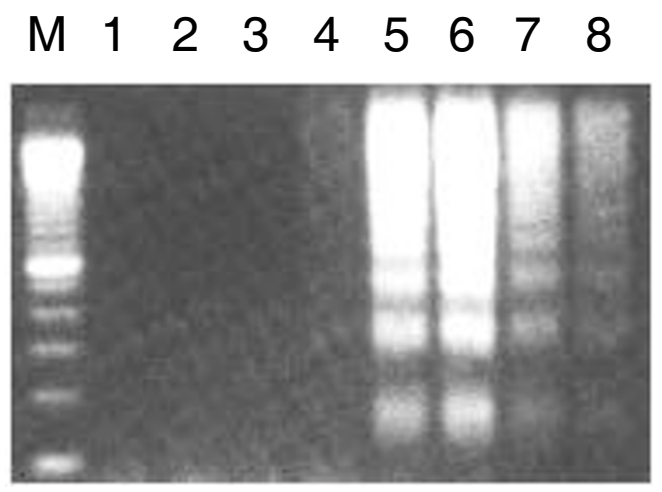

Figure 3. Internucleosomal DNA fragmentation induced by nickel (II) acetate. (A) DNA extracted with phosphate citrate buffer from untreated and treated $\mathrm{CHO}$ cells was analyzed by $1.8 \%$ agarose gel electrophoresis. Lanes: 1 , untreated for $72 \mathrm{~h} ; 2,40$ (M; 3, 80 (M; 4, 160 (M; 5, 240 (M; 6, 480 (M; 7, 640 (M nickel (II) acetate treatment. (B) Time course of apoptosis appearing as DNA ladder in cells treated with 480 (M nickel (II) acetate. Lanes 1, untreated; $2,12 \mathrm{~h} ; 3,24 \mathrm{~h} ; 4,48 \mathrm{~h} ; 5,72 \mathrm{~h} ; 6,4$ day; 7, 5 day; 8,6 day after treatment; M, $100 \mathrm{bp}$ DNA molecular weight marker. following nickel (II) treatment (Data not shown). But, proportion of $\mathrm{CHO}$ cells in each phase didn't showed significant change, from $55.7 \%$ in the $\mathrm{G}_{0} / \mathrm{G}_{1}$ phase, $25.0 \%$ in the $S$ phase, and $19.3 \%$ in the $\mathrm{G}_{2} / \mathrm{M}$ phase of cells treated with $0 \mu \mathrm{M}$ nickel (II) for $48 \mathrm{~h}$, to $66.6 \%, 15.9 \%$, and $17.5 \%$ for $640 \mu \mathrm{M}$ nickel (II).

In our experiments, we observed the obvious dosedependent accumulation of cells in the $\mathrm{G}_{2} / \mathrm{M}$ phase. Also, the data for apoptosis showed a dose-dependent occurrence. Thus, it seemed that the cells underwent nickel (II)-induced apoptosis during or after mitotic failure and consequently, prevented the cell cycle progression through $G_{1}$ and $S$ phase. However, we could not rule out the possibility that the apoptosis is occurring in the cells arrested in $G_{2} / M$ phase. The concurrence of $G_{2} / M$ cell accumulation with apoptosis in response to nickel (II) indicates that a common signal is sent to prevent damaged cells from further replication and to eliminate them. DNA damage results in arrest of cells in the $G_{1}$

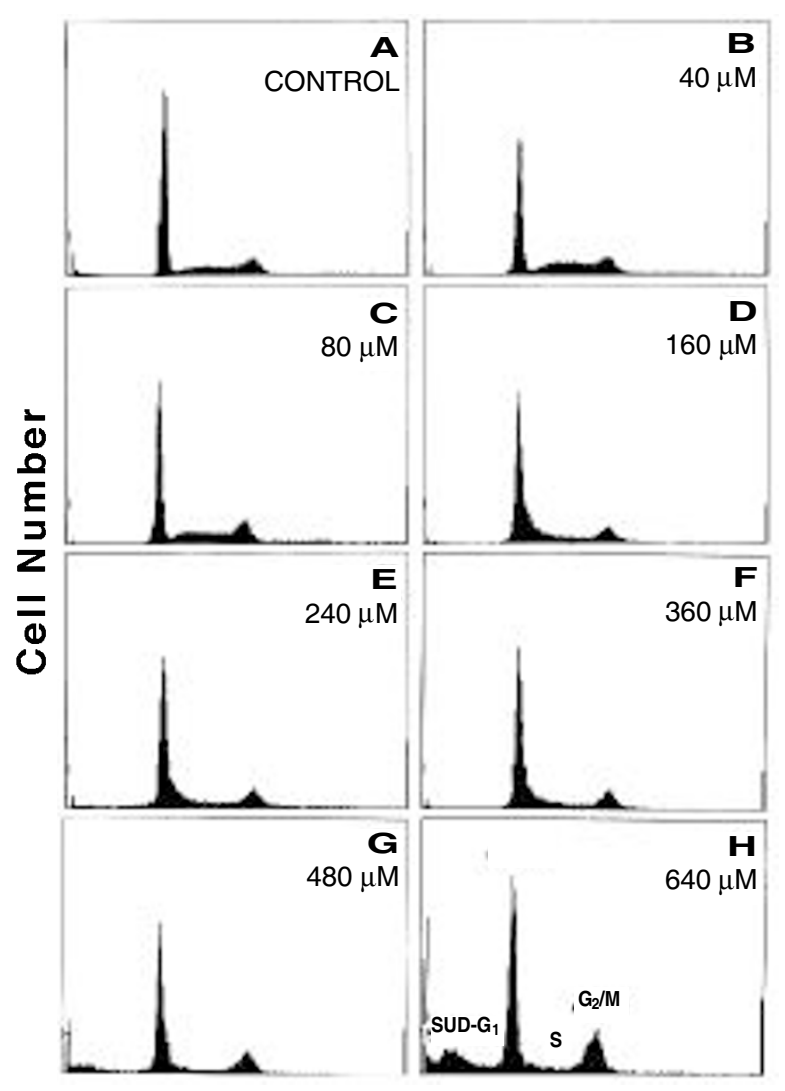

Figure 4. Cell distribution at $\mathrm{G} 1, \mathrm{~S}$, and $\mathrm{G} 2 / \mathrm{M}$ phases among nickel (II) acetatetreated cells. Propidium iodide-stained cells were analyzed by EPICS profile flow cytometry to determine the cell cycle distribution. (A) untreated, (B) treated with 40 (M, (C) 80 (M, (D) 160 (M, (E) 240 (M, (F) 360 (M, (G) 480 (M, and (H) 640 (M nickel (II) acetate for $72 \mathrm{~h}$. 
Table 1. Cell cycle distribution of $\mathrm{CHO}$ cells treated with different concentrations of nickel (II) acetate

\begin{tabular}{cccr}
\hline Nickel $(\mathrm{II})(\mu \mathrm{M})$ & $\mathrm{G}_{0} / \mathrm{G}_{1} \%$ & $\mathrm{~S} \%$ & \multicolumn{1}{c}{$\mathrm{G} 2 / \mathrm{M} \%$} \\
\hline 0 & $57.7 \pm 3.5$ & $34.7 \pm 3.1$ & $7.6 \pm 1.5$ \\
40 & $53.8 \pm 4.8$ & $36.8 \pm 2.7$ & $8.7 \pm 1.5$ \\
80 & $52.4 \pm 3.1$ & $35.3 \pm 5.2$ & $12.2 \pm 2.5$ \\
160 & $51.1 \pm 4.8$ & $38.7 \pm 5.1$ & $10.1 \pm 0.5$ \\
240 & $61.7 \pm 4.7$ & $28.7 \pm 2.1$ & $9.5 \pm 3.6$ \\
360 & $64.2 \pm 3.0$ & $23.2 \pm 2.1$ & $12.5 \pm 3.9$ \\
480 & $59.4 \pm 2.8$ & $16.3 \pm 3.0$ & $24.2 \pm 5.3$ \\
640 & $58.6 \pm 2.8$ & $14.5 \pm 3.2$ & $26.9 \pm 0.6$ \\
\hline
\end{tabular}

(Dulic et al., 1994) and $\mathrm{G}_{2}$ phases (Sit and Chen, 1997) of the cell cycle through mechanisms involving the $\mathrm{G}_{1}$ and $G_{2}$ phase checkpoints, respectively. Damaged cells stop DNA replication at $G_{1}$ or $G_{2}$ phase, presumably allowing cells to repair DNA lesions prior to mitosis. Apoptosis is also triggered in response to various DNA damage. A similar activation of $\mathrm{G}_{2} / \mathrm{M}$ arrest and apoptosis have been also observed in a number of report (Kim et al., 1993; Demarcq et al., 1994; Smith and Fornace, 1996). Concurrence of these cellular responses has been associated with $\mathrm{p} 34^{\mathrm{cdc}}$ kinase inhibition by dephosphorylation (Lock and Ross, 1990). However, the molecular mechanism has not been clearly determined. The progression of cells through mitosis after the exposure to DNA damaging agents has been suggested to be facilitated by $\mathrm{p} 53$ protein, whereas p53-deficient cells are stalled in $\mathrm{G}_{2}$ thereby triggering apoptosis (Guillouf et al., 1995; Stewart et al., 1995; Wahl et al., 1996). Also, other proteins involved in cell cycle can be associated with both apoptosis and $\mathrm{G}_{2} / \mathrm{M}$ arrest. Further investigations seem to be necessary to find out the common effector(s).

In summary, we have demonstrated that nickel (II) acetate, DNA damaging agent, induced apoptosis and $\mathrm{G}_{2} / \mathrm{M}$ cell accumulation. Concurrence of these cellular responses suggests that common effector(s) may be activated to regulate cell growth and cell death in response to DNA damage.

\section{References}

Allday, M. J., Inman, G. J., Crawford, D. H. and Farrell, P. J. (1995) DNA damage in human $B$ cells can induce apoptosis, proceding from $G_{1} / S$ when $p 53$ is transactivation competent and $\mathrm{G}_{2} / \mathrm{M}$ when it is transactivation defective. EMBO J. 14: 4994-5005

Arends, M. J., Morris, R. G. and Wyllie, A. H. (1990) The role of the endo-nuclease. Am. J. Pathol. 136: 593-608

Brezden, C. B. and Rauth, A. M. (1996) Differential cell death in immor-talized and nonimmortalized cells at confluency. Oncogene 12: 201-206

Costa, M. (1978) Alteration in morphology of Chinese hamster ovary cells by Ni3S2 and dibutyryl cAMP. Appl. Pharmacol. 44: 555-566

Darzynkiewicz, Z., Bruno, S., Del Bino, G., Gorczyca, W., Hotz, M. A., Lassota, P. and
Traganos, F. (1992) Features of apoptotic cells measured by flow cytometry. Cytometry 13: $795-808$

Demarcq, C., Bunch, R. T., Creswell, D. and Eastman, A. (1994) The role of cell cycle progression in cisplastin-induced apoptosis in Chinese hamster ovary cells. Cell Growth Differ. 5: 983-993

Dulic, V., Kaufman, W. K., Wilson, S., Tlsty, T., Lees, E., Harper, J. W., Elledge, S. J. and Reed, S. I. (1994) p53-dependent inhibition of cyclin-dependent kinase activities in human fibroblasts during radiation-induced $\mathrm{G}_{1}$ arrest. Cell 76: 1013-1023

Gong, J., Traganos, F. and Darzynkiewicz, Z. (1994) A selective procedure for DNA extraction from apoptotic cells applicable for gel electrophoresis and flow cytometry. J. Cell Physiol. 65: 314-319

Guillouf, C., Rosselli, F., Krishnaraju, K., Moustacchi, E., Hoffman, B. and Liebermann, A. (1995) p53 involvement in control of $\mathrm{G}_{2}$ exit of the cell cycle: role in DNA damageinduced apoptosis. Oncogene 10: 2263-2270

Kallioniemi, O. P., Visakorpi, T., Holli, K., Isola, J. J. and Rabinovitch, P. S. (1994) Automated peak detection and cell cycle analysis of flow cytometric DNA histogram. Cytometry 16: 250-255

Kasprzak, K. S. (1995) Possible role of oxidative damage in metal-induced carcinogenesis. Cancer Invest. 13: 411-430

Kim, I. K., Lee, J. H., Sohn, H. W., Kim, H. S. and Kim, S. H. (1993) Prostaglandin A2 and $\Delta^{12}$-prostaglandin $J_{2}$ induce apoptosis in L1210 cells. FEBS Lett. 321: 209-214

King, K. L. and Cidlowski, J. A. (1995) Cell cycle and apoptosis: Common pathway to life and death. J. Cell. Biochem. 58: 175-180

Lock, R. B. and Ross, W. E. (1990) Inhibition of p34cdc2 kinase activity by etoposide or irradiation as a mechanism of $\mathrm{G}_{2}$ arrest in Chinese hamster ovary cells. Cancer Res. 50: $3761-3766$

Lowe, S. W., Ruley, H. E., Jacks, T. and Housman, D. E. (1993) p53-dependent apoptosis modulates the cytotoxicity of anticancer agents. Cell 74: 957-967

O'Connor, P. M., Ferris, D. K., Pagano, M., Draetta, G., Pines, J., Hunter, T., Longer, D. L. and Kohn, K. W. (1993) G2 delay induced by nitrogen mustard in human cells affects cyclin A/cdk2 and cyclin B/cdc2 kinase complexes differently. J. Biol. Chem. 268: 82988308

Schedle, A., Samorapoompichit, P., Rausch-Fan, X. H., Franz, A., Fureder, W., Sperr, W. R., Ellinger, A., Slavicek, R., Boltz-Nitulescu, G. and Valent, P. (1995) Response of L929 fibroblasts, human gingival fibroblasts, and human tissue mast cells to various metal cations. J. Dent. Res. 74: 1513-1520

Sellins, K. S. and Cohen, J. J. (1991) Cytotoxic T lymphocytes induce different types of DNA damage in target cells of different origins. J. Immunol. 147: 795-803

Sit, K. H. and Chen, D. L. (1997) Transient G2M arrest and subsequent release of apoptotic and mitotic cells in vanadyl(4)-prepulsed human Chang liver cells. Cell Death Differ. 4: 216-223

Smith, M. L. and Fornace, A. J. Jr. (1996) Mammalian DNA damage-inducible genes associated with growth arrest and apoptosis. Mutat. Res. 340: 109-124

Stewart, N., Hick, G. G., Paraskevas, F. and Mowat, M. (1995) Evidence for a second cell cycle block at $G_{2} / M$ by p53. Oncogene $10: 109-115$

Wahl, A. F., Donaldson, K. L., Fairchild, C., Lee, F. Y., Foster, S. A., Demers, G. W. and Galloway, D. A. (1996) Loss of normal p53 function confers sensitization to taxol by increasing $\mathrm{G}_{2} / \mathrm{M}$ arrest and apoptosis. Nature Med. 2: $72-79$

Walker P. R., Pandey, S. and Sikorska, M. (1995) Degradation of chromatin in apoptosis. Cell Death Differ. 2: 97-104

Watanabe-Fukanaga, R., Brannan, C. I., Copeland, N. G., Jenkins, N. A. and Nagata, S. (1992) Lymphoproliferation disorder in mice explained by defects in Fas antigen that mediates apoptosis. Nature 356: 314-317

Wyllie A. H. (1980) Glucocorticoid-induced thymocyte apoptosis is associated with endogenous endonuclease activation. Nature 284: 555-556 
